\title{
Does Political Instability lead to higher and more volatile inflation? A Panel Data Analysis
}

\author{
Ari Aisen \\ UCLA \\ Francisco José Veiga* \\ Universidade do Minho - NIPE
}

\begin{abstract}
Economists generally accept the proposition that high and volatile inflation rates generate inefficiencies that reduce society's welfare. Furthermore, studies have shown that inflation is harmful to economic growth. However, determining the causes of the worldwide diversity of inflationary experiences is an important challenge not yet satisfactorily confronted by the profession. Based on a broad dataset covering over 100 countries for the period 1975-1997 and using dynamic and static panel data econometric techniques, this paper shows that a higher degree of political instability is associated with both higher inflation levels and volatility. Not only does this paper advance the political economy literature establishing a relationship between inflation moments and political instability, but it also has important policy implications regarding the optimal design of inflation stabilization programs and of the institutions favorable to price stability.
\end{abstract}

Keywords: Inflation, volatility, political instability, institutions.

JEL codes: E31, E63.

\footnotetext{
${ }^{*}$ The authors wish to thank Carlos Végh and Henry Chappell for very helpful comments. Francisco Veiga also wishes to express his gratitude for the financial support of the Portuguese Foundation for Science and Technology (FCT), under research grant POCTI/32491/ECO/2000, and acknowledge the research assistance of Helena Fernandes.
} 


\section{Introduction}

It is generally recognized that high and volatile inflation rates generate inefficiencies that reduce society's welfare. ${ }^{1}$ Given the costs associated with high inflation it may seem odd that so many countries have experienced it. The great diversity of inflationary processes across countries is also a puzzling phenomenon. One possible explanation relies on different characteristics of the tax systems resulting from unequal levels of development and/or economic structures. Countries with inefficient tax systems have to resort more frequently to seigniorage revenues, thus increasing inflation. Several political economy models rely on the characteristics of the political systems and institutions to explain the diversity of macroeconomic policies adopted and, consequently, the diversity of inflation rates observed. Suboptimal policies leading to high inflation could result from political instability, polarization or weak institutions.

The main purpose of this paper is to empirically determine the main causes of the worldwide diversity of inflationary experiences, a challenge not yet satisfactorily confronted by the profession for three fundamental reasons. First, there is no empirical work that thoroughly examines the determinants of inflation volatility. Second, empirical models explaining inflation levels in the literature generally fail to account for inflation inertia and for the endogeneity of important economic and political variables affecting inflation. We use GMM estimation applied to dynamic panel data introduced by Arellano and Bond (1991) to address some of the econometric limitations of the OLS models previously used in the literature. Third, the advent of new datasets, such as the DPI from Beck et al. (2001), with more recent data for existing and new political and economic variables greatly facilitates the measurement of political instability, which may be related to high inflation. The use of this and other data sources combined with

\footnotetext{
${ }^{1}$ For a textbook exposition of the costs of inflation, see Romer (2001, 519-523). Empirical studies, such as Fisher, Sahay and Végh (2002), show that high inflation is detrimental to GDP per capita growth and to economic performance in general.
} 
modern econometric techniques might provide more accurate estimations of relationships between inflation levels and political instability.

Relying upon the previously noted theories and using a dataset covering 154 countries for the period 1975-97, we investigate the main economic and political determinants of inflation levels and volatility. After controlling for the countries' economic structure and for the behavior of economic variables that may influence inflation, we find that political instability leads to higher and more volatile inflation. Furthermore, the impact of political instability on inflation levels and volatilities is much stronger for high inflation than for moderate and low inflation countries and also seems to be stronger for developing than for industrial nations. Additionally, institutions such as economic freedom and democracy are important determinants of inflation. In particular, higher degrees of economic freedom are associated with lower inflation levels and volatility.

The paper is structured as follows. A description of worldwide inflation patterns and a literature review on the relationship between inflation and political instability/institutions are presented in section 2. The dataset and the empirical models are described in section 3 . Section 4 presents the empirical results and section 5 concludes the paper.

\section{Political instability, institutions and inflation}

For our purposes, it should be extremely informative to analyze cross-regional inflation data worldwide. The high diversity observed in the 23-year period of 19751997 is striking; for example, note that average yearly inflation in Latin America and Caribbean (LAC) countries of roughly $150 \%$ is more than 20 times higher than the average inflation in the industrial countries for the same period. African countries also 
endured average inflation rates of over $100 \%$ a year in the period, while Asian countries had average inflation lower than $20 \%$. The chart below shows average inflation for the period 1975-1997 for each region of the world.

Average Inflation in the World (1975-1997)

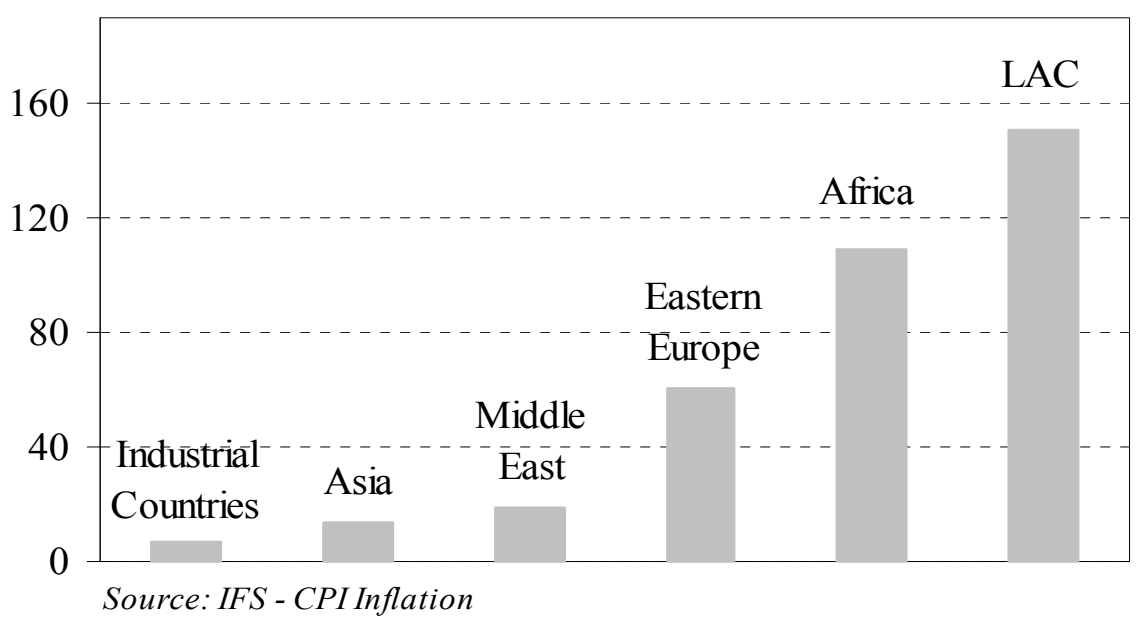

The existence of high variability of inflation rates around the world is well known. However, economists are less aware of the cross-regional differences in inflation volatilities. The chart below shows inflation volatility calculated using the coefficient of variation (standard deviation divided by mean).

Inflation Volatility in the World (1975-1997)

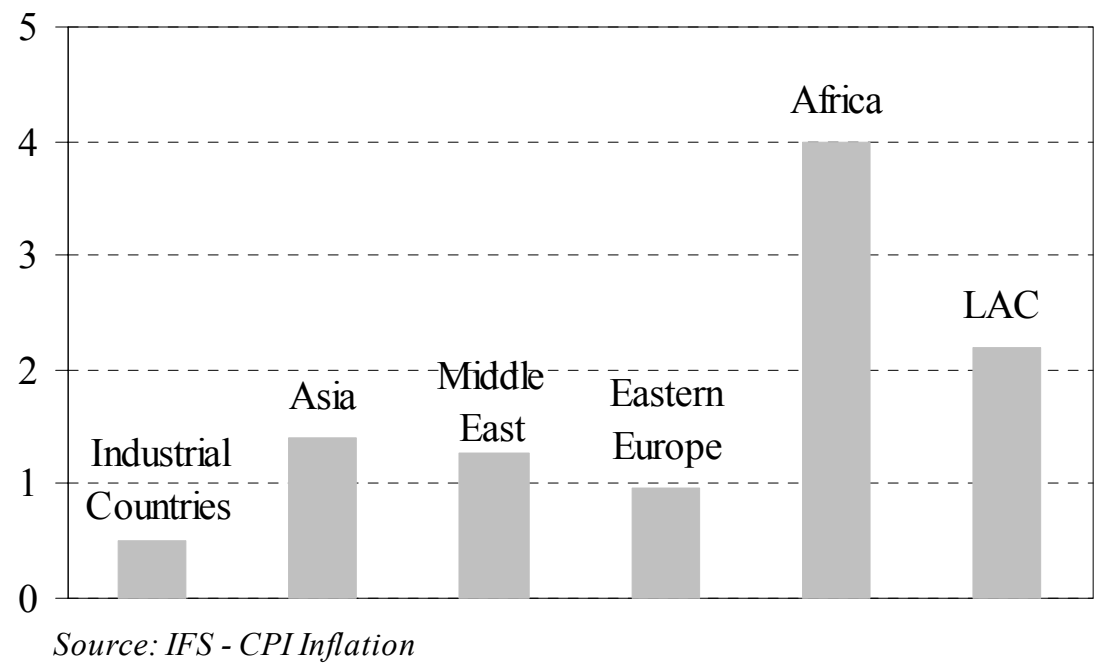


The variability observed in inflation volatilities is also very high. In Africa, for example, inflation is at least eight times more volatile than in the Developed World. LAC also shows high volatility, with inflation roughly four times more volatile than in the developed countries. A quick analysis of the charts above indicates a close relationship between inflation levels and volatility. As pointed out by Fischer, Sahay and Vegh (2002), the higher the inflation rate, the more volatile and unstable it becomes. The remainder of this section and sections 3 and 4 of the paper elucidate the reasons behind the cross-country variability in inflation levels and volatility relating it to political instability.

Most economists acknowledge that differences in monetary and fiscal policies among countries are the main reasons behind the inflation variability they sustain. But this explanation leads to a much deeper and fundamental question, which is why countries differ on the way they conduct fiscal and monetary policies. Many attempts have been made to explain theoretically and empirically the high inflation levels observed in different countries, taking into account the deeper sources of inflation. Edwards and Tabellini (1991) offer a survey of the theoretical explanations. One expalanation, perhaps most applicable to developed countries is based upon the Theory of Optimal Taxation (see Phelps, 1973; Vegh, 1989; and Aizenman, 1992). According to this theory, governments optimally equate the marginal cost of the inflation tax with the marginal cost of output taxes. An appropriate procedure to test the validity of this theory is to verify if data on variations of income taxes and variations in inflation are positively correlated and close to one. Edwards and Tabellini (1991) fail to find evidence that the Theory of Optimal Taxation applies to the developing countries. In 
fact, they find evidence that political instability measured by government changes and polarization lead to higher inflation in these countries. A theoretical rationale for this finding is provided by the models of Alesina and Tabellini (1990) and Tabellini and Alesina (1990), who analyze the effects of political instability and polarization on the determination of fiscal deficits and debt. If a government believes it has a small probability of remaining in power, it might finance additional expenditures with debt issuance since it does not internalize the costs associated with debt repayment and it also constrains the government expenditures of the party that wins the next election. This process results in higher deficits and debt. According to this theory, politically unstable and more polarized countries should present higher fiscal deficits and higher and more volatile inflation.

Cukierman, Edwards and Tabellini (1992) provided evidence showing that higher degrees of political instability lead to higher inflation rates. This measure of instability was derived from a probit model that attempted to explain the likelihood that an incumbent government would remain in power. In the empirical analysis of section 4, we employ alternative measures of instability; we use variables that count the exact number of government crises or cabinet changes taking place in a particular year. These variables are equally capable or superior in reflecting political instability and instability of economic policies than the variable used by Cukierman et al. (1992). Two shortcomings of the analysis in Cukierman et al. (1992) are the presence of endogeneity in some explanatory variables and the absence of explanatory variables accounting for inflation inertia.

Why should a greater number of cabinet changes or government crises lead to higher and more volatile inflation? First, in a country characterized by frequent changes in the composition of government, there are also frequent changes in macroeconomic 
policies, as new prime ministers or ministers of finance/economics do not necessarily share the views of their predecessors. Then, these changes in macroeconomic policies lead to higher inflation volatility. Second, frequent cabinet changes and government crises shorten the horizon of the members of government, as they are not certain that they will keep their posts during an entire term. The higher the probability of being replaced, the greater will be the importance attributed to short-term objectives. Then, it is difficult to maintain low and stable inflation.

Paldam (1987) studies the relation between inflation and political instability in eight Latin American countries. He argues that this relation works both ways. The main connections from inflation to instability would be related to the costs of inflation and to the responsibility hypothesis, according to which people hold governments responsible for economic outcomes. One very robust result of the vote and popularity functions literature $^{2}$ is that higher inflation is associated with lower popularity and votes. Thus, when inflation rises, the probability that the current government will remain in power decreases. The causality from politics to inflation would be primarily related to the demand for public expenditures (which weak governments seldom resist) that are then financed by the inflation tax. Later on, when inflation has risen to high levels, it will be much harder for a weak and unstable government to resist the political pressures asking for accommodating policies..

The importance of political cohesion has also been stressed in the literature. Drazen (2000) shows that interest groups want other groups to bear the costs of disinflation since they consider it a public good. Very fragmented societies with a variety of interest groups and weak political institutions are unable to make tough decisions and change the status quo in the face of adverse economic circumstances. In

\footnotetext{
${ }^{2}$ See Nannestad and Paldam (1994) for a survey.
} 
the case of societies suffering from chronic inflation, rates of inflation tend, according to this theory, to be more persistent, higher and more volatile. ${ }^{3}$ Some authors have also stressed the importance of institutions on economic performance. Acemoglu et al. (2002) show that institutions are a very important element explaining growth rates for a cross-section of different countries. In the next sections we also estimate the impact of institutions on inflation levels and volatility.

Finally, the literature studying developing countries also addresses a set of structural variables affecting the ability of governments to collect taxes. According to this structural view, the taxing capacity of a country is technologically constrained by its stage of development and by the structure of the economy and, therefore, as tax collecting costs are high and tax evasion pervasive, countries might use the inflation tax more consistently as the primary way to finance their government expenditures.

Overall, the theoretical and empirical literature surveyed support the view that higher degrees of political instability are associated with higher inflation rates. It is natural to think that the different elements behind the explanation of inflation levels should also be present in a study of inflation volatility. Therefore, we do not only review the issue of inflation levels, but we also add to the literature analyzing crosscountry differences in inflation volatility.

\section{Data and the empirical model}

The dataset is composed of annual data on political, institutional and economic variables for 154 countries, for the years 1975 to 1997 . The choice of the period of

\footnotetext{
${ }^{3}$ The literature on "wars of attrition" between conflicting interest groups was initiated by Alesina and Drazen (1991). Veiga (2000) provides empirical evidence that higher fragmentation of the political system leads to greater delays of inflation stabilization.
} 
analysis was driven by the fact that the Database of Political Institutions (version 3.0), ${ }^{4}$ from which we collect data on many political and institutional variables, covers these 23 years. The other sources of political and institutional data are: the Cross National Time Series Data Archive of the Inter-University Consortium for Political and Social Research; the Polity IV (Political Regime Characteristics and Transitions) dataset; ${ }^{5}$ the 2002 Annual Report of the Economic Freedom of the World (Gwartney and Lawson, $2002) ;{ }^{6}$ and the Freedom House ratings on political rights and civil liberties. ${ }^{7}$ Economic data was collected from the World Bank's World Development Indicators and Global Development Finance, the International Monetary Fund's International Financial Statistics and Direction of Trade Statistics, the OECD Statistical Compendium, and Dollar (1992). Appendix 1 presents a description of all variables used, grouped by sources.

The objective of our empirical exercise is to investigate the main political, institutional and economic determinants of inflation levels and volatility across countries and time. This is done estimating dynamic panel data models for annual inflation levels and static panel data models for standard deviations of inflation for consecutive 3-year periods. Since inflation levels and standard deviations have very high variability, their logarithms were used as our dependent variables: $\log (\operatorname{Inf})$, stands for the $\log$ of inflation levels and $\log [S D(\operatorname{Inf})]$ stands for the $\log$ of the standard deviation of inflation. We hypothesize that these depend on the following explanatory variables:

\footnotetext{
${ }^{4}$ On this database, see Beck et al. (2001). Available on the Internet though Philip Keefer's page in the World Bank's site (http://www.worldbank.org/research/bios/pkeefer.htm).

${ }_{6}^{5}$ Available on the Internet (http://www.cidcm.umd.edu/inscr/polity/index.htm).

${ }^{6}$ Available on the Internet (http://www.freetheworld.com/release.html). This report presents data on the index of economic freedom and its components for the years 1970, 1975, 1980, 1985, 1990, 1995 and 2000. In order to avoid a great number of missing values in our sample, straight-line interpolation was used to generate annual data.

${ }^{7}$ Available on the Internet (http://www.freedomhouse.org/ratings/).
} 
- Lagged logarithm of inflation, L.Log(Inf). Given the abundant evidence of inflation inertia found in empirical studies, a positive coefficient is expected for L.Log(inf).

- A set of variables representing political instability and institutions:

○ Cabinet changes, Cabchg, is our main proxy for political instability. It is defined as follows: the number of times in a year that a new premier is named and/or $50 \%$ of the cabinet posts are occupied by new ministers. This definition means that a cabinet change occurs only when there are very important changes in the composition of government. These can result from several events: an election won by a party that was previously in the opposition; a government crisis in which the government does not fall, but at least $50 \%$ of the ministers are replaced; the government falls, and a new one is formed by parties previously in the opposition, without the need to anticipate elections; a coup d'etat or a revolution leads to a change of government. According to the models described in section 2, this variable should be positively related to inflation levels and volatility (positive coefficients are expected).

- Index of economic freedom, Index. Higher indexes are associated with smaller governments (Area I), stronger legal structure and security of property rights (Area II), access to sound money (Area III), greater freedom to exchange with foreigners (Area $I V$ ), and more flexible regulations of credit, labor, and business (Area $V$ ). All of these are characteristics of advanced and liberalized economies where seigniorage and other forms of distortionary taxation are generally absent. Thus, we expect that greater economic freedom is associated with lower inflation levels and volatilities (negative coefficients are expected). 
○ Polity scale, Polity2: ranges from strongly autocratic (-10) to strongly democratic (10). Although industrialized countries have low inflation and are democratic, in developing countries, which are the majority in our sample, authoritarian/autocratic regimes may be better able to control inflation, as Haggard and Kaufman (1992) and Paldam (1987) suggest. Thus, when all countries are considered, we expect positive coefficients for this variable.

- A set of economic structural variables that reflect characteristics of the countries that may affect their capacity to control inflation:

- The share of the value added of agriculture in GDP, Agric_va. According to Cukierman, Edwards and Tabellini (1992), the agricultural sector is the hardest to tax, which implies greater reliance on seigniorage revenues in countries where its share of GDP is higher. Thus, positive coefficients are expected for this variable, as seigniorage leads to inflation;

○ GDP per capita, GDP $\_p p$. Following Cukierman, Edwards and Tabellini (1992), we expect this variable to have a negative coefficient, since the technology for enforcing tax collection is likely to be less efficient in poorer and less developed countries, leading to greater use of seigniorage revenues;

- Openness to trade, Trade. We expect positive coefficients for this variable because countries with a larger foreign trade sector are more exposed to external shocks that may increase inflation levels and volatility ${ }^{8}$

- Variables accounting for economic performance and external shocks:

○ Growth of real GDP, GDP_gr. Fisher, Sahay and Végh (2002), and others, find that periods of high inflation are characterized by contractions in the

\footnotetext{
${ }^{8}$ Edwards and Tabellini (1991) indicate that greater openness to trade may favor the adoption of traderelated taxes in developing countries reducing the need of other distortionary forms of taxation such as the inflation tax. According to their view, greater openness to trade should be associated with lower inflation. Possibly, one could argue that the sign of the coefficient of trade openness is the net effect of two opposing channels affecting inflation namely, external exposure to shocks and tax substitutability.
} 
levels of GDP. Thus, a negative coefficient is expected for this variable in the estimations for inflation levels. Given the consensus in the economic literature that inflation is bad for growth, this variable was treated as endogenous. Since inflation volatility may be better explained by the volatility of GDP growth, the standard deviation of the latter, $S D\left(G D P \_g r\right)$, was used in the estimations for $\log [S D(\operatorname{Inf})]$. Again, a negative coefficient is expected and the variable is treated as endogenous;

- Real effective overvaluation of the national currency, Real_over. Negative signs are expected, as an overvalued currency leads to cheaper imports and brings inflation down. Since current inflation can affect the real exchange rate if nominal exchange rates to not float freely, this variable is treated as endogenous;

- Logarithm of inflation levels, $\log (\operatorname{Inf})$. This variable is included in the estimations for inflation volatility because, according to Fisher, Sahay and Végh (2002), the latter is positively related to inflation levels. Thus, a positive coefficient is expected in the models for $\log [S D(\operatorname{Inf})]$;

○ Percentage annual change in oil prices, Oil. Since higher oil prices lead to greater costs of production and prices, they are associated with higher and more volatile inflation (positive coefficients are expected).

Although we consider that high inflation results in most cases from high budget deficits that are monetized, we decided not to include money growth and deficits in our baseline model because, as stated in the previous section, we are searching for the deep determinants of inflation. That is, we intent to find out the reasons why monetary and fiscal policies are not always consistent with low inflation.

The empirical model for inflation levels can be summarized as follows: 


$$
\operatorname{Inf}_{i t}=\alpha \operatorname{Inf} f_{i, t-1}+\mathbf{X}_{i, t}^{\prime} \boldsymbol{\beta}_{1}+\mathbf{W}_{i, t}^{\prime} \boldsymbol{\beta}_{2}+v_{i}+\varepsilon_{i t} \quad i=1, \ldots, N \quad t=1, \ldots, T_{i}
$$

where Inf stands for the inflation level of country $i$ at time $t, \alpha$ is a parameter to be estimated, $\beta_{1}$ and $\beta_{2}$ are vectors of parameters to be estimated, $\mathbf{X}$ is a vector of strictly exogenous covariates, $\mathbf{W}$ is a vector of endogenous covariates, $v$ are the fixed effects for each country, and, $\varepsilon$ is the error term.

Substantial complications arise in the estimation of this model using OLS. In both the fixed and random effects settings, the difficulty is that the lagged dependent variable is correlated with the error term, even if we assume that the disturbances are not themselves autocorrelated. If the number of observations per country, $T_{i}$, is small, the fixed or random effects estimators will be inconsistent. ${ }^{9}$ Since in the estimations for annual inflation levels we have a maximum of 22 observations per country, $T$ should be treated as small, implying that OLS estimations will not be efficient.

Arellano and Bond (1991) developed a generalized method of moments (GMM) estimator that solves the problems referred to above. First differencing (1) removes $v_{i}$ and produces an equation estimable by instrumental variables:

$$
D \cdot \operatorname{Inf}_{i t}=\alpha D \cdot \operatorname{Inf}_{i, t-1}+D \cdot \mathbf{X}_{i, t}^{\prime} \boldsymbol{\beta}_{1}+D \cdot \mathbf{W}_{i, t}^{\prime} \boldsymbol{\beta}_{2}+D \cdot \varepsilon_{i t}
$$

where $D$ is the first difference operator and the variables and parameters are defined as in (1). The Arellano-Bond dynamic panel-data estimator uses the following instruments: levels of the dependent variable lagged two and more periods; levels of the endogenous variables lagged two and more periods; and, the first differences of the strictly exogenous covariates, which are used as their own instruments.

The empirical model for inflation volatility can be summarized as follows:

$$
S D\left(\operatorname{Inf}_{i t}\right)=\mathbf{X}_{i, t}^{\prime} \boldsymbol{\beta}_{1}+\mathbf{W}_{i, t-1}^{\prime} \boldsymbol{\beta}_{2}+v_{i}+\varepsilon_{i t} \quad i=1, \ldots, N \quad t=1, \ldots, T_{i}
$$

\footnotetext{
${ }^{9}$ See Greene (2000), chapter 14, and Arellano and Bond (1991).
} 
where $S D($ Inf) stands for the standard deviation of inflation of country $i$ for the 3-year period $t, \beta_{1}$ and $\beta_{2}$ are vectors of parameters to be estimated, $\mathbf{X}$ is a vector of strictly exogenous covariates, $\mathbf{W}$ is a vector of endogenous covariates (which are lagged one period), $v$ are the fixed effects for each country, and, $\varepsilon$ is the error term.

The next section shows the results of Arellano-Bond linear dynamic panel-data estimations for annual inflation levels and Within Groups (fixed effects) estimations for 3-year period standard deviations of inflation.

\section{Empirical Results}

The first empirical exercise consisted in finding the deep economic and political determinants of inflation levels across countries and time. After dealing with annual inflation, we searched for the main determinants of inflation volatility, using a panel of standard deviations of inflation for consecutive 3-year periods.

\section{a) Results for annual inflation}

The results of the Arellano-Bond linear dynamic panel-data estimations for a dataset of annual data from 1975 to 1997 are shown in Table 1. As stated in the previous section, this methodology estimates the model in first differences. Thus, the dependent variable is the first difference (D1) of $\log ($ inf) and the explanatory variables are in first differences as well.

We started by estimating the model only with economic variables. Results are shown in column 1 of Table 1 . The first lag of the dependent variable is statistically significant and the coefficient has a positive sign, confirming our expectation that there is substantial inflation persistence. Concerning structural variables, the value-added of the agricultural sector as a percentage of GDP (Agric_va) has the expected sign but is 
weakly statistically significant only in the estimation of column 4 , and foreign trade as a percentage of GDP (Trade) has a positive coefficient, indicating that greater openness to trade leads to higher inflation. ${ }^{10}$ With respect to economic performance, results are as expected: Real Gross Domestic Product growth, GDP_gr, and real effective exchange rate overvaluation, Real_over, have negative signs, confirming our intuition that inflation is associated with lower growth and undervalued currencies. Finally, the annual change in the price of oil (Oil_ch) has a positive sign, as expected, and is statistically significant.

\section{--- Insert Table 1 about here ---}

Our next exercise was to add the political variables described in the last section, so that one could see whether they also contribute to the explanation of the great diversity of inflationary experiences over countries and time. Except for Cabchg in column 2 and AreaI and AreaII in column 3, the political variables are always statistically significant, which implies that they help explain inflation levels, even after controlling for a set of economic variables that affect inflation. The number of cabinet changes that occur within a year, Cabchg, has a positive sign, as expected, but is only statistically significant in the estimation of column 3 . When the number of government crises, Govcrise, is included in the model instead of cabinet changes, the result is stronger - more government crises clearly lead to higher inflation (see column 4). Since these variables representing political instability are affected by inflation, they were treated as endogenous, which means that the Arellano-Bond estimator uses their levels lagged two or more periods as instruments.

\footnotetext{
${ }^{10}$ GDP per capita, GDP _ ppp , was never statistically significant when included in the estimations of Table
} 1. These, and other results not shown, are available from the authors upon request. 
The index of economic freedom, Index, has a negative sign, as expected, indicating that greater economic freedom leads to lower inflation. When the index is decomposed in its five areas (see column 3), we get the results that the size of governments (AreaI) and the legal structure and the security of property rights (AreaII) do not affect inflation, while access to sound money (AreaIII), freedom to exchange with foreigners (AreaIV) and more flexible credit, labor and business regulations $($ AreaV $)$ are associated with lower inflation. The positive coefficient associated with the polity scale, Polity2, may imply that autocracies are better at keeping inflation low than democracies, as Haggard and Kaufman (1992) and Paldam (1987) suggest. This result may also be influenced by the fact that most of the famous hyperinflation episodes took place in democratic regimes.

Column 1 of Table 2 shows the results of an estimation in which cabinet changes, Cabchg, are interacted with dummy variables accounting for inflation below and above 50 percent. Fisher, Sahay and Végh (2002) classify annual inflation as very high if it is equal to or greater than $100 \%$, as high for the $50-100$ percent range, moderate for the $25-50$ percent range, and low if it is below $25 \%$. In the estimations of Table 2, we use two dummy variables based on this classification: $\operatorname{Inf} \geq 50$, that accounts for high and very high inflation, takes the value of one if inflation is greater than or equal to $50 \%$, and zero otherwise; and, $\operatorname{Inf}<50$, that accounts for moderate and low inflation, takes the value of one if inflation is lower than $50 \%$, and zero otherwise. ${ }^{11}$ The interaction of cabinet changes, Cabchg, with inflation below 50 percent is not statistically significant, while the interaction of Cabchg with $\operatorname{Inf} \geq 50$ is highly statistically significant and has a positive sign. Thus, the weak results concerning Cabchg shown in Table 1 may be due to the fact that cabinet changes are not associated

\footnotetext{
${ }^{11}$ Dummies were also constructed for inflation below and above $100 \%$. When these dummy variables are included in the model instead of $\operatorname{Inf} \geq 50$ and $\operatorname{Inf}<50$ results are virtually the same.
} 
with higher inflation in low inflation countries. But, when we turn to episodes of high and very high inflation, there is a clear positive relationship between the number of cabinet changes that occur in a year (our proxy for political instability) and inflation.

\section{--- Insert Table 2 about here ---}

In column 2, Govcrise, the number of government crises that occurred in a given year, was used instead of Cabchg. Now, there is weak evidence that political instability is positively associated with inflation also in low and moderate inflation episodes. Nevertheless, the statistical significance and size of the coefficient of Govcrise*(Inf $\geq 50)$ are much greater than those for Govcrise* $(\operatorname{Inf}<50)$, indicating that the association between political instability and inflation is much stronger when the latter is high. In column 3, Govcrise was interacted with dummy variables for industrial (Ind_co) and developing countries (Dev_co). Results are in line with the ones described above. The interaction of government crises, Govcrise, with industrial countries is not statistically significant and the interaction of Govcrise with Dev_co is highly statistically significant and has a positive sign. Thus, the positive relation between government crises and inflation found in Table 1 is true essentially for developing countries (the ones that are responsible for the majority of the episodes of high and very high inflation). ${ }^{12}$

According to the models of Cukierman, Edwards and Tabellini (1992) and Alesina and Drazen (1991), lower political cohesion (higher fragmentation) leads to greater political instability and delayed stabilizations, resulting in higher inflation. Column 4 shows the results obtained when we interact the index of political cohesion,

\footnotetext{
${ }^{12}$ When Cabchg is interacted with Ind_co and Dev_co, the interaction variables are not statistically significant.
} 
Ipcoh, ${ }^{13}$ with $\operatorname{Inf} \geq 50$ and $\operatorname{Inf}<50$. Results indicate that lower cohesion (or greater fragmentation) leads to higher inflation, as expected, but only in countries suffering from high or very high inflation. When the latter is low or moderate, the interaction variable is not statistically significant. ${ }^{14} 15$

\section{b) Results for inflation volatility}

The second part of our empirical exercise consisted in investigating the main determinants of inflation volatility. For that purpose, we performed several Within Groups (fixed effects) estimations for a panel of the logarithm of standard deviations of inflation for 3-year periods. ${ }^{16}$ According to Fisher, Sahay and Végh (2002), inflation volatility is positively related to inflation levels. Thus, we expect that most of the variables that affect inflation levels are also determinants of inflation volatility. For that reason, most of the explanatory variables used in the models for inflation levels are also included in the models for inflation volatility (they are now expressed as 3-year averages). Furthermore, the level of inflation should also help explain its standard deviation.

As for inflation levels, we start with a model that includes only the economic variables referred to in section 3 . The results of column 1 of Table 3 show that the

\footnotetext{
${ }^{13}$ Ipcoh is based on the index of political cohesion created by Roubini and Sachs (1989). These authors showed that, for OECD countries, smaller cohesion would be associated with larger budget deficits.

${ }^{14}$ When Ipcoh is included in the model without any interactions, it is not statistically significant. The same happens with the interactions of Ipcoh with Ind_co and Dev_co Results are virtually equal when we use Frac, total fractionalization, instead of Ipcoh.

${ }^{15}$ A series of robustness tests not shown here were also performed. These consisted in adding more variables to the base model (column 2 of Table 1) or in replacing some variables for reasonable alternatives. We found that the following changes lead to higher inflation: greater executive constraints, Exconst (when this variable replaces Polity2); more leftist governments (higher Execrlc); smaller index of political rights, Pol_right; smaller index of civil liberties, Civil_lib; and, lower tax revenues as a percentage of GDP, Reven_GDP.

${ }^{16}$ The periods are: $1975-7 \overline{7}, 1978-80,1981-83,1984-86,1987-89,1990-92,1993-1995$, and 1996-1997.
} 
lagged dependent variable is not statistically significant, ${ }^{17}$ which means that inflation volatility is not persistent along 3-year periods. When this lagged dependent variable is excluded we get a static panel data model that can be estimated by the Within Groups (fixed effects) estimator without incurring in problems of inconsistency. ${ }^{18}$ The logarithm of inflation averages, $\log (\operatorname{Inf})$, is highly statistically significant, indicating that inflation becomes more volatile at higher levels. But, since the correlation between the average and the standard deviation of inflation for 3-year periods is very high, it is more appropriate to exclude $L o(\operatorname{Inf})$ from the model. ${ }^{19}$ In fact, it should be noted that there are a some changes in results when $\log [S D(\operatorname{Inf})](-1)$ and $\log (\operatorname{Inf})$ are excluded: Trade and Oil_ch are no longer statistically significant, while Real_over becomes significant.

\section{--- Insert Table 3 about here ---}

The remaining columns of Table 3 report a series of tests that consist in adding political and institutional variables to the model. ${ }^{20}$ Cabchg has the expected sign but is not statistically significant (column 3 ). ${ }^{21}$ But, an alternative indicator of political instability works better in these estimations for the standard deviation of inflation: Exetchg, the average number of times in a year that the effective control of the executive power changes hands, is statistically significant when we use it instead of Cabchg (column 4). Less economic freedom (smaller Index), greater ideological

\footnotetext{
${ }^{17}$ The same result is obtained when we use the Arellano-Bond estimator instead of the Within Groups (fixed effects) estimator.

${ }^{18}$ Hausmann tests clearly indicate that the fixed effects specification is preferable to a random effects model and to a simple OLS.

${ }^{19}$ The correlation between $\log (\operatorname{In} f)$ and $\log [S D(\operatorname{Inf})]$ is equal to $77.45 \%$. The correlation between $\operatorname{Inf}$ and $S D(I N f)$ is even higher $(99.1 \%)$.

${ }^{20}$ The variables Trade, $S D(G D P$ gr $)(-1)$ and Oil_ch were excluded from the model. They are never statistically significant when included in the models of columns 2 to 6 .

${ }^{21}$ The p-value is .107 , which means that Cabchg is almost weakly statistically significant.
} 
polarization, (Polariz2), and lower Herfindhall index (greater fragmentation) of the parties' shares in Parliament, Herftot, lead to higher inflation volatility.

These results concerning political instability, polarization, and fragmentation are consistent with the models of Alesina and Drazen (1991) and Cukierman, Edwards and Tabellini (1992) and with the empirical results of Veiga (2000) that imply that greater polarization, fragmentation and political instability lead to the delay of inflation stabilization programs, resulting in higher inflation rates and, consequently, in higher inflation volatility. ${ }^{22}$

\section{Conclusions}

The data show a strikingly high variability of inflation levels and volatilities around the world. Using the linear dynamic panel data GMM estimator suggested by Arellano and Bond (1991) and the Within Groups (fixed effects) estimator on a sample covering 154 countries analyzed in the period from 1975 to 1997 , this paper finds that a higher degree of political instability, measured through several political and institutional variables, generates higher and more volatile inflation rates. Higher average numbers of cabinet changes, government crises or changes in the effective executive, measure not only political instability but also economic policy variability, since every new cabinet that takes over power might have a new set of preferences regarding inflation and unemployment levels. In addition, since every new government is inserted in a very unstable political and institutional environment, it is also very likely to be removed in a short period of time. These perverse mechanisms greatly affect the way governments conduct monetary and fiscal policies generating higher and more volatile inflation rates.

\footnotetext{
${ }^{22}$ Robustness tests that consisted in adding variables to the model of column 4 of Table 3 revealed that the following are associated with higher inflation volatility: higher fractionalization of the Parliament, Frac; more leftist governments (higher Execrlc); lower civil liberties, Civil_lib; lower economic growth of trading partners, GDP_gr_tp; lower US Treasury Bill rates, TBill_rate; higher or more volatile external debt as a percentage of GDP, Ext_debt; and, more volatile government debt, Gov_debt.
} 
We have also shown that the mechanisms indicated above are more pervasive and stronger in developing and, especially, in high inflation (above 50\%) countries than in the developed and low inflation world.

The above-mentioned results are in line with those obtained by Paldam (1987), Edwards and Tabellini (1991) and Cukierman, Edwards and Tabellini (1992) regarding the positive relationship between political instability and inflation in developing countries. Nonetheless, we further advance this literature by showing that inflation volatility is also affected in a similar way by the political environment. Given the costs in terms of economic growth and welfare generated by inflation volatility, we believe that this is an important contribution, not only for positive economics, but also in a normative way. Policy-makers in developing countries should be aware that it is essential to reform institutions and create viable mechanisms conducive to long-run price stability. Besides, inflation stabilization efforts may be only temporarily effective if they do not include serious fiscal and political reforms. ${ }^{23}$

\section{References}

Aizenman, Joshua, 1992. Competitive Externalities and the Optimal Seignoriage. Journal of Money, Credit and Banking, 24(1), 61-71.

Acemoglu, Daron, Simon Johnson, James Robinson and Yunyong Thaicharoen, 2002. Institutional causes, macroeconomic symptoms: volatility, crises and growth. NBER Working Paper 9124, September.

Alesina, Alberto and Allan Drazen, 1991, Why are Stabilizations Delayed? American Economic Review 81(5), 1170-1188.

\footnotetext{
${ }^{23}$ Veiga (1999) clearly shows that budget deficits are among the main causes of the failure of inflation stabilization programs implemented in chronic inflation countries.
} 
Alesina, Alberto and Guido Tabellini, 1990. A Positive Theory of Fiscal Deficits and Government Debt. Review of Economics Studies 57(3), 403-414.

Arellano, Manuel and Stephen Bond, 1991. Some tests of specification for panel data: Monte Carlo evidence and an application to employment equations. The Review of Economic Studies 58: 277-297.

Beck, Thorsten, George Clarke, Alberto Groff, Philip Keefer, and Patrick Walsh, 2001. New tools in comparative political economy: the Database of Political Institutions. The World Bank Economic Review 15(I), 165-176.

Cukierman, Alex, Sebastian Edwards, and Guido Tabellini, 1992. Seignioriage and Political Instability. American Economic Review 82(3), 537-555.

Dollar, David, 1992. Outward-Oriented Developing Economies Really Do Grow More Rapidly: Evidence from 95 LDCs, 1976-1985. Economic Development and Cultural Change 40(3): 523-44

Drazen, Alan 2000. Political Economy in Macroeconomics (Princeton University Press, New Jersey).

Edwards, Sebastian and Guido Tabellini, 1991. Explaining Fiscal Policy and Inflation in Developing Countries. Journal of International Money and Finance 10, Supplement, S16-S48.

Fisher, Stanley, Ratna Sahay and Carlos Végh, 2002. Modern Hyper- and High Inflations. Journal of Economic Literature XL(3), 837-880.

Greene, William, 2000. Econometric Analysis, $4^{\text {th }}$ edition (Prentice-Hall, New Jersey).

Gwartney, James and Robert Lawson, 2002. Economic Freedom of the World - 2002 Annual Report. (Fraser Institute, Vancouver, B.C.).

Haggard, Stephan and Robert R. Kaufman, 1992. The Political Economy and Stabilization in Middle-Income Countries, in: Haggard, Stephan and Robert R. 
Kaufman, eds., The Politics of Economic Adjustment (Princeton University

Press, Princeton, NJ), 270-315.

Nannestad, Peter and Martin Paldam, 1994. The VP-function: A survey of the literature on vote and popularity functions after 25 years. Public Choice 79, 213-245.

Paldam, Martin, 1987. Inflation and Political Instability in eight Latin American countries 1946-83. Public Choice 52, 143-168.

Phelps, Edmund 1973. Inflation in the Theory of Public Finance. Swedish Journal of Economics 75, 67-82

Romer, David, 2001. Advanced Macroeconomics, $2^{\text {nd }}$ edition. (McGraw-Hill, New York).

Roubini, Nouriel and Jeffrey Sachs, 1989. Political and Economic Determinants of Budget Deficits in the Industrial democracies. European Economic Review 33, 903-938.

Tabellini, Guido and Alberto Alesina, 1990. Voting on the Budget Deficit. The American Economic Review 80(1), 37-49.

Végh, Carlos, 1989. Government Spending and Inflationary Finance: A Public Finance Approach. IMF Staff Papers, Vol. 36, 657-77.

Veiga, Francisco José, 1999. What causes the failure of inflation stabilizations plans? Journal of International Money and Finance 18(2), 169-194.

Veiga, Francisco José, 2000. Delays of inflation stabilizations. Economics and Politics $12(3), 275-295$. 
Table 1: Results for yearly inflation

\begin{tabular}{|c|c|c|c|c|c|}
\hline $\log (\operatorname{Inf})$ & D1 & 1 & 2 & 3 & 4 \\
\hline $\log (\operatorname{Inf})$ & LD1 & $\begin{array}{c}.516 \\
(8.07)^{* * *}\end{array}$ & $\begin{array}{c}.470 \\
(7.91)^{* * *}\end{array}$ & $\begin{array}{c}.406 \\
(6.86)^{* * *}\end{array}$ & $\begin{array}{c}.463 \\
(7.71)^{* * *}\end{array}$ \\
\hline Cabchg & D1 & & $\begin{array}{l}.042 \\
(.93)\end{array}$ & $\begin{array}{c}.080 \\
(1.83)^{*}\end{array}$ & \\
\hline Govcrise & D1 & & & & $\begin{array}{c}.227 \\
(3.49)^{* * *}\end{array}$ \\
\hline Index & D1 & & $\begin{array}{c}-.399 \\
(-4.90)^{* * *}\end{array}$ & & $\begin{array}{c}-.394 \\
(-4.95)^{* * *}\end{array}$ \\
\hline Area I & D1 & & & $\begin{array}{c}.074 \\
(1.34)\end{array}$ & \\
\hline Area II & D1 & & & $\begin{array}{l}.039 \\
(.99)\end{array}$ & \\
\hline Area III & D1 & & & $\begin{array}{c}-.095 \\
(-3.29)^{* * *}\end{array}$ & \\
\hline Area IV & D1 & & & $\begin{array}{c}-.191 \\
(-2.95)^{* * *}\end{array}$ & \\
\hline Area V & D1 & & & $\begin{array}{c}-.228 \\
(-1.75)^{*}\end{array}$ & \\
\hline Polity2 & D1 & & $\begin{array}{c}.025 \\
(2.71)^{* * *}\end{array}$ & $\begin{array}{c}.033 \\
(3.33)^{* * *}\end{array}$ & $\begin{array}{c}.024 \\
(2.83)^{* * *}\end{array}$ \\
\hline Agric_va & D1 & $\begin{array}{c}.023 \\
(1.61)\end{array}$ & $\begin{array}{c}.026 \\
(1.43)\end{array}$ & $\begin{array}{c}.030 \\
(1.24)\end{array}$ & $\begin{array}{c}.028 \\
(1.67)^{*}\end{array}$ \\
\hline Trade & D1 & $\begin{array}{c}.012 \\
(3.48)^{* * *}\end{array}$ & $\begin{array}{c}.019 \\
(7.03)^{* * *}\end{array}$ & $\begin{array}{c}.021 \\
(7.24)^{* * *}\end{array}$ & $\begin{array}{c}.020 \\
(7.45)^{* * *}\end{array}$ \\
\hline GDP_gr & D1 & $\begin{array}{c}-.046 \\
(-5.24)^{* * *}\end{array}$ & $\begin{array}{c}-.032 \\
(-4.68) * * *\end{array}$ & $\begin{array}{c}-.029 \\
(-4.14)^{* * *}\end{array}$ & $\begin{array}{c}-.030 \\
(-4.61)^{* * *}\end{array}$ \\
\hline Real_over & D1 & $\begin{array}{l}-.001 \\
(-.83)\end{array}$ & $\begin{array}{c}-.002 \\
(-2.40)^{* *}\end{array}$ & $\begin{array}{c}-.002 \\
(-1.80)^{*}\end{array}$ & $\begin{array}{c}-.002 \\
(-2.28)^{* *}\end{array}$ \\
\hline Oil_ch & D1 & $\begin{array}{c}.003 \\
(4.09)^{* * *}\end{array}$ & $\begin{array}{c}.003 \\
(4.69)^{* * *}\end{array}$ & $\begin{array}{c}.003 \\
(3.98)^{* * *}\end{array}$ & $\begin{array}{c}.003 \\
(4.44)^{* * *}\end{array}$ \\
\hline \multicolumn{2}{|c|}{ \# Observations } & 1607 & 1396 & 1209 & 1394 \\
\hline \multicolumn{2}{|c|}{ \# Countries } & 99 & 88 & 88 & 88 \\
\hline \multicolumn{2}{|c|}{ Sargan test (Prob>Chi2) } & 1.00 & 1.00 & 1.00 & 1.00 \\
\hline
\end{tabular}

Sources: see Appendix 1.

Notes: - Arellano-Bond dynamic panel-data estimation (using Stata 8);

- Z-statistics are in parenthesis. Significance level at which the null hypothesis is rejected: $* * *, 1 \% ; * *, 5 \%$, and $*, 10 \%$

- D1 stands for first difference and LD1 for one-time lagged first difference;

- "Sargan test" is the test for over-identifying restrictions;

- Second order autocorrelation of residuals is always rejected. 
Table 2: Results using interaction variables

\begin{tabular}{|c|c|c|c|c|c|}
\hline $\log (\operatorname{Inf})$ & D1 & 1 & 2 & 3 & 4 \\
\hline $\log (\operatorname{Inf})$ & LD1 & $\begin{array}{c}.446 \\
(7.68)^{* * *}\end{array}$ & $\begin{array}{c}.454 \\
(7.76)^{* * *}\end{array}$ & $\begin{array}{c}.466 \\
(8.17)^{* * *}\end{array}$ & $\begin{array}{c}.453 \\
(8.03)^{* * *}\end{array}$ \\
\hline Cabchg*(Inf<50) & D1 & $\begin{array}{l}-.023 \\
(-.60)\end{array}$ & & & \\
\hline Cabchg $*(\operatorname{Inf} \geq 50)$ & D1 & $\begin{array}{c}.497 \\
(5.41)^{* * *}\end{array}$ & & & \\
\hline Govcrise*(Inf<50) & D1 & & $\begin{array}{c}.095 \\
(1.75)^{*}\end{array}$ & & \\
\hline Govcrise* $(\operatorname{Inf} \geq 50)$ & D1 & & $\begin{array}{c}.676 \\
(4.47)^{* * *}\end{array}$ & & \\
\hline Govcrise*Ind_co & D1 & & & $\begin{array}{c}.127 \\
(1.28)\end{array}$ & \\
\hline Govcrise*Dev_co & D1 & & & $\begin{array}{c}.241 \\
(3.18)^{* * *}\end{array}$ & \\
\hline $\operatorname{Ipcoh*}(\operatorname{Inf}<50)$ & D1 & & & & $\begin{array}{c}-.053 \\
(-1.40)\end{array}$ \\
\hline $\operatorname{Ipcoh} *(\operatorname{Inf} \geq 50)$ & D1 & & & & $\begin{array}{c}.400 \\
(2.69)^{* * *}\end{array}$ \\
\hline Index & D1 & $\begin{array}{c}-.363 \\
(-4.86)^{* * *}\end{array}$ & $\begin{array}{c}-.361 \\
(-4.78)^{* * *}\end{array}$ & $\begin{array}{c}-.390 \\
(-5.00)^{* * *}\end{array}$ & $\begin{array}{c}-.350 \\
(-4.45)^{* * *}\end{array}$ \\
\hline Polity2 & D1 & $\begin{array}{c}.026 \\
(3.25)^{* * *}\end{array}$ & $\begin{array}{c}.024 \\
(3.25)^{* * *}\end{array}$ & $\begin{array}{c}.026 \\
(3.48)^{* * *}\end{array}$ & $\begin{array}{c}.026 \\
(2.84)^{* * *}\end{array}$ \\
\hline Agric_va & D1 & $\begin{array}{c}.018 \\
(1.24)\end{array}$ & $\begin{array}{c}.022 \\
(1.56)\end{array}$ & $\begin{array}{c}.026 \\
(1.58)\end{array}$ & $\begin{array}{c}.016 \\
(1.24)\end{array}$ \\
\hline Trade & D1 & $\begin{array}{c}.018 \\
(6.74)^{* * *}\end{array}$ & $\begin{array}{c}.019 \\
(7.60)^{* * *}\end{array}$ & $\begin{array}{c}.019 \\
(7.26)^{* * *}\end{array}$ & $\begin{array}{c}.019 \\
(6.24)^{* * *}\end{array}$ \\
\hline GDP_gr & D1 & $\begin{array}{c}-.031 \\
(-4.94)^{* * *}\end{array}$ & $\begin{array}{c}-.027 \\
(-4.76)^{* * *}\end{array}$ & $\begin{array}{c}-.029 \\
(-4.70) * * *\end{array}$ & $\begin{array}{c}-.034 \\
(-4.55)^{* * *}\end{array}$ \\
\hline Real_over & D1 & $\begin{array}{c}-.002 \\
(-2.58)^{* * *}\end{array}$ & $\begin{array}{c}-.002 \\
(-2.23)^{* *}\end{array}$ & $\begin{array}{c}-.002 \\
(-2.31)^{* * *}\end{array}$ & $\begin{array}{c}-.002 \\
(-2.47)^{* *}\end{array}$ \\
\hline Oil_ch & D1 & $\begin{array}{c}.003 \\
(5.09)^{* * *}\end{array}$ & $\begin{array}{c}.003 \\
(4.44)^{* * *}\end{array}$ & $\begin{array}{c}.003 \\
(4.54)^{* * *}\end{array}$ & $\begin{array}{c}.003 \\
(4.38)^{* * *}\end{array}$ \\
\hline \multicolumn{2}{|l|}{ \# Observations } & 1396 & 1394 & 1394 & 1395 \\
\hline \multicolumn{2}{|l|}{ \# Countries } & 88 & 88 & 88 & 87 \\
\hline \multicolumn{2}{|c|}{ Sargan test (Prob $>$ Chi2) } & 1.00 & 1.00 & 1.00 & 1.00 \\
\hline
\end{tabular}

Sources: see Appendix 1.

Notes: - Arellano-Bond dynamic panel-data estimation (using Stata 8);

- Z-statistics are in parenthesis. Significance level at which the null hypothesis is rejected: ***, $1 \% ; * *, 5 \%$, and $*, 10 \%$

- D1 stands for first difference and LD1 for one-time lagged first difference;

- "Sargan test" is the test for over-identifying restrictions;

- Second order autocorrelation of residuals is always rejected. 
Table 3: Inflation volatility for 3 year periods

\begin{tabular}{|c|c|c|c|c|c|c|}
\hline $\log [\operatorname{SD}(\operatorname{Inf})]$ & 1 & 2 & 3 & 4 & 5 & 6 \\
\hline $\log [\operatorname{SD}(\operatorname{Inf})](-1)$ & $\begin{array}{l}-.037 \\
(-.83)\end{array}$ & & & & & \\
\hline $\log (\operatorname{Inf})$ & $\begin{array}{c}.874 \\
(12.49)^{* * *}\end{array}$ & & & & & \\
\hline Cabchg (-1) & & & $\begin{array}{c}.210 \\
(1.61)\end{array}$ & & & \\
\hline Exetchg (-1) & & & & $\begin{array}{c}.382 \\
(2.31)^{* *}\end{array}$ & $\begin{array}{c}.311 \\
(1.82)^{*}\end{array}$ & $\begin{array}{c}.331 \\
(1.79)^{*}\end{array}$ \\
\hline Index & & & $\begin{array}{c}-.638 \\
(-3.99)^{* * *}\end{array}$ & $\begin{array}{c}-.621 \\
(-3.95)^{* * *}\end{array}$ & $\begin{array}{c}-.574 \\
(-3.70)^{* * *}\end{array}$ & $\begin{array}{c}-.678 \\
(-4.43)^{* * *}\end{array}$ \\
\hline Agric_va & $\begin{array}{c}.027 \\
(2.09)^{* *}\end{array}$ & $\begin{array}{c}.067 \\
(3.42)^{* * *}\end{array}$ & $\begin{array}{c}.046 \\
(2.25)^{* *}\end{array}$ & $\begin{array}{c}.047 \\
(2.24)^{* *}\end{array}$ & $\begin{array}{c}.051 \\
(2.34)^{* *}\end{array}$ & $\begin{array}{c}.027 \\
(1.20)\end{array}$ \\
\hline GDP_ppp & $\begin{array}{l}-.00004 \\
(-2.36)^{* *}\end{array}$ & $\begin{array}{c}-.0001 \\
(-8.03)^{* * *}\end{array}$ & $\begin{array}{c}-.0001 \\
(-3.11)^{* * *}\end{array}$ & $\begin{array}{c}-.0001 \\
(-3.17)^{* * *}\end{array}$ & $\begin{array}{c}-.0001 \\
(-3.61)^{* * *}\end{array}$ & $\begin{array}{c}-.0001 \\
(-3.24)^{* * *}\end{array}$ \\
\hline Trade & $\begin{array}{c}-.011 \\
(-2.59) * * *\end{array}$ & $\begin{array}{l}.0006 \\
(.13)\end{array}$ & & & & \\
\hline $\mathrm{SD}\left(\mathrm{GDP} \_\mathrm{gr}\right)(-1)$ & $\begin{array}{c}-.017 \\
(-1.51)\end{array}$ & $\begin{array}{l}.005 \\
(.32)\end{array}$ & & & & \\
\hline Real_over (-1) & $\begin{array}{l}.0004 \\
(.41)\end{array}$ & $\begin{array}{c}.002 \\
(2.21)^{* *}\end{array}$ & $\begin{array}{c}.002 \\
(1.58)\end{array}$ & $\begin{array}{c}.002 \\
(1.51)\end{array}$ & $\begin{array}{c}.002 \\
(1.57)\end{array}$ & $\begin{array}{l}-.001 \\
(-.32)\end{array}$ \\
\hline Oil_ch & $\begin{array}{c}-.004 \\
(-1.77)^{*}\end{array}$ & $\begin{array}{c}-.004 \\
(-1.31)\end{array}$ & & & & \\
\hline Polariz2 & & & & & $\begin{array}{c}.308 \\
(2.53)^{* *}\end{array}$ & \\
\hline Herftot & & & & & & $\begin{array}{c}-.761 \\
(-2.05)^{* *}\end{array}$ \\
\hline \# Observations & 569 & 593 & 563 & 563 & 549 & 515 \\
\hline \# Countries & 97 & 97 & 90 & 90 & 90 & 89 \\
\hline Adjusted $\mathrm{R}^{2}$ & 69 & .51 & .55 & .55 & .58 & .57 \\
\hline
\end{tabular}

Sources: see Appendix 1.

Notes: - Within Groups (fixed effects) estimations (using TSP 4.5);

- Models estimated with a constant;

- T-statistics are in parenthesis. Significance level at which the null hypothesis is rejected: $* * *, 1 \% ; * *, 5 \%$, and $*, 10 \%$ 
Appendix 1: Description of the variables used by source

\author{
Database of Political Institutions (DPI) \\ Execrlc $\rightarrow$ Executive Party Orientation: 1=Right, 2=Centre, 3=Left, $0=$ Not \\ applicable (for all those cases which do not fit into other mentioned \\ category), Blank (for those cases where orientation is unknown) \\ Frac $\rightarrow$ Total Fractionalization (Chance that two random draws will produce \\ legislators from different parties) \\ Herftot $\quad \rightarrow$ Herfindahl Index Total The sum of the squared shares of all parties in \\ parliament. \\ Ipcoh $\quad \rightarrow$ Index of Political Cohesion: \\ Presidential systems: \\ $=0$ when the same party controls the executive and legislature \\ $=1$ if different parties control the executive and legislature \\ Parliamentary systems: \\ $=0$ for a one-party majority government \\ $=1$ for a coalition government with two parties \\ $=2$ for a coalition government with three or more parties \\ $=3$ for a minority government \\ Polariz2 $\rightarrow$ Ideological Polarization (Maximum difference of orientation among \\ government parties (0-2))
}

\title{
Cross National Times Series Data Archive (CNTS)
}

Cabchg $\rightarrow$ Number of Cabinet Changes (the number of times in a year that a new premier is named and/or $50 \%$ of the cabinet posts are occupied by new ministers)

Exetchg $\rightarrow$ Changes in Effective Executive (the number of times in a year that the effective control of the executive power changes hands)

Govcrise $\rightarrow$ Number of Government Crises (rapidly developing situations that threaten to bring the downfall of the present regime - excluding situations of revolt aimed at such overthrow)

\section{Polity IV}

Exconst $\rightarrow$ Executive Constraints (this variable refers to the extent of institutional constraints on the decision-making powers of the chief executive, whether an individual or a collective executive)

Polity2 $\rightarrow$ Polity (polity scale, ranging from 10 (strongly democratic) to -10 (strongly autocratic) 


\section{Freedom House Rankings}

Pol_right $\rightarrow$ Political Rights: is measured on a one-to-seven scale, with one representing the highest degree of freedom and seven the lowest.

Civil_lib $\rightarrow$ Civil Liberties: is measured on a one-to-seven scale, with one representing the highest degree of freedom and seven the lowest.

\section{Economic Freedom of the World (2002 Annual Report)}

Area I $\quad \rightarrow \quad$ Size of Government: Expenditures, Taxes, and Enterprises

Area II $\quad \rightarrow \quad$ Legal Structure and Security of Property Rights

Area III $\rightarrow$ Access to Sound Money

Area IV $\quad \rightarrow \quad$ Freedom to Exchange with Foreigners

Area V $\quad \rightarrow \quad$ Regulation of Credit, Labor, and Business

Index $\rightarrow$ Summary Index (of the 5 areas above)

World Development Indicators (WDI) - World Bank

$\begin{array}{lll}\text { Agric_va } & \rightarrow & \text { Agriculture, value added (\% of GDP) } \\ \text { Ext_debt } & \rightarrow & \text { External debt (\% of GDP) } \\ \text { GDP_gr } & \rightarrow & \text { Real GDP growth (annual \%) } \\ \text { GDP_ppp } & \rightarrow & \text { GDP per capita, PPP (current international \$) } \\ \text { Gov_debt } & \rightarrow & \text { Central Government Debt \%GDP } \\ \text { Reven_gdp } & \rightarrow & \text { Tax revenue }(\% \text { of GDP) } \\ \text { Trade } & \rightarrow & \text { Trade }(\% \text { of GDP) }\end{array}$

International Financial Statistics (IFS) - IMF

TBill_rate $\rightarrow$ Treasury Bill Rate - USA (code 60C)

Inf $\quad \rightarrow \quad$ Changes in consumer prices, percent per annum (code $64 \mathrm{X}$ )

Other sources or combination of sources

GDP_gr_tp $\quad \rightarrow \quad$ Trading Partners' GDP Per Capita growth $(\%$, weighted average by trade share): IMF Directions of Trade Statistics (for trade data); Global Development Finance \& World Development Indicators (for GDP per capita growth).

Oil $\quad \rightarrow \quad$ Index for the price of oil: OECD Statistical Compendium.

Real_over $\quad \rightarrow \quad$ Real Overvaluation (using the real overvaluation index developed by Dollar (1992)): Global Development Finance \& World Development Indicators. 